\title{
Aplikasi Surat Izin Usaha Perdagangan (SIUP) Pada Badan Penanaman Modal Dan Perizinan Terpadu Kota Banjarmasin
}

\author{
Wagino \\ Fakultas Teknologi Informasi, Universitas Islam Kalimantan Muhammad Arsyad Al-Banjari \\ ginouniska@gmail.com \\ Dr. Silvia Ratna \\ Fakultas Teknologi Informasi, Universitas Islam Kalimantan Muhammad Arsyad Al-Banjari \\ via.borneo@gmail.com \\ Fathur Rahman \\ Fakultas Teknologi Informasi, Universitas Islam Kalimantan Muhammad Arsyad Al-Banjari \\ fathur234@gmail.com
}

\begin{abstract}
Abstrak
Penelitian ini dengan judul "Aplikasi Surat Izin Usaha Perdagangan (SIUP) Pada Badan Penanaman Modal Dan Perizinan Terpadu Kota Banjarmasin" bertujuan untuk menghasilkan suatu sistem atau aplikasi untuk mempermudah kinerja proses perizinan pada Badan Penanaman Modal Dan Perizinan Terpadu Kota Banjarmasin. Perizinan SIUP (Surat Izin Usaha Perdagangan) secara komputerisasi dapat mempermudah dari pihak pemohon untuk mendaftarkan perusahaannya pada BPMPT (Badan Penanaman Modal Dan Perizinan Terpadu) dan juga dari pihak BPMPT untuk meminimalisir SDM (Sumber Daya Manusia) yang ada dan dalam pengarsipan data dapat lebih rapi dan lebih tahan lama. Sistem Ini dirancang dengan mengguankan Bahasa pemrograman borland delphi 7 dan menggunakan database Microsoft Acces. Diharapkan dengan adanya aplikasi ini pekerjaan penerbitan SIUP dan pengarsipan pada Badan Penanaman Modal Dan Perizinan Terpadu Kota Banjarmasin menjadi lebih mudah dan efektif.
\end{abstract}

Keywords : BPMPT, Aplikasi, Informasi, Perdagangan 


\section{PENDAHULUAN}

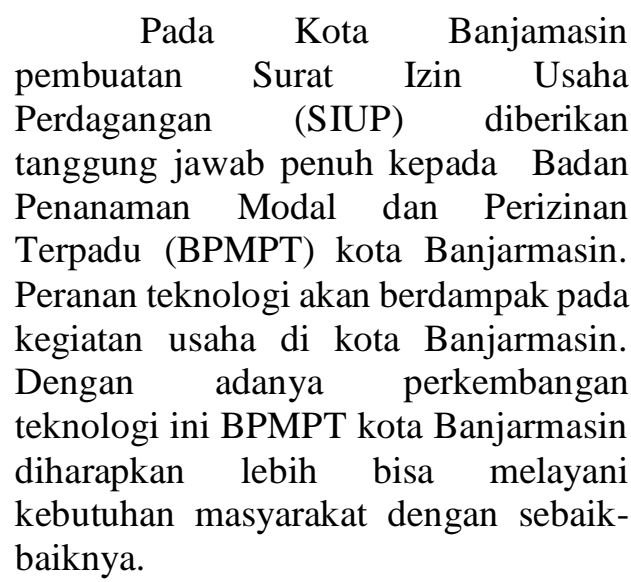

Palayanan Surat Ijin Usaha Pedagangan (SIUP) di BPMPT kota Banjarmasin merupakan pekerjaan yang melibatkan beberapa bagian terkait dan memerlukan banyak orang dalam proses pembuatannya. Diantaranya yang dimulai dengan pengajuan permohonan, pengecekan data pemohon, pengecekan lokasi pemohon, hingga diterbitkannya SIUP. Sehingga sangat perlu tingkat ketelitian yang tinggi untuk suatu pemprosesan penerbitan SIUP.

Banyaknya pemohon SIUP mengakibatkan BPMPT kota Banjarmasin mengalami kesulitan dalam hal pengecekan data dari para pemohon. Data pemohon yang tidak dikelola secara komputerisasi mengakibatkan kesulitan dalam pemrosesan. Sehingga sering kali banyak data pemohon yang terselip dengan data pemohon lainnya. Persoalan ini mengakibatkan SIUP tidak bisa segera terproses oleh petugas yang bertugas menangani SIUP tersebut. Sehingga pemohon harus bersabar lebih lama untuk mendapatkan SIUP ini, sehingga tidak banyak pemohon yang tidak terlayani dengan sebaik-baiknya.

Sehubungan dengan kondisi tersebut, maka muncul gagasan untuk membuat suatu pengembangan yaitu sistem aplikasi, khususnya yang menyangkut penerbitan SIUP di kantor BPMPT kota Banjarmasin.
Berdasarkan uraian dan kondisi di atas maka hasil rancangan tersebut dituangkan dalam bentuk manajemen perancangan aplikasi dengan judul "Aplikasi Surat Izin Usaha Perdagangan (Siup) Pada Badan Penanaman Modal Dan Perizinan Terpadu Kota Banjarmasin"

\section{METODE PENELITIAN}

Metode yang digunakan dalam penelitian ini yaitu metode System Development Life Cycle (SDLC) dengan model Waterfall. Metode ini mempunyai keunggulan dapat menjamin aplikasi yang dibuat memiliki kualitas yang sangat baik karena pengerjaannya yang bertahap, selain juga menjamin dokumentasi aplikasi yang menjadi lebih mudah dan baik. Berikut tahapantahapan dari metode Waterfall (Pressman, 2010):

1. Analisa kebutuhan, tahapan ini adalah tahapan paling awal. Pada tahapan ini akan ditentukan input yang diperlukan, proses yang dilakukan oleh sistem dan output yang akan dihasilkan sehingga dapat ditentukan kebutuhan dan hasil dari aplikasi.

2. Desain sistem, pada tahapan ini hasil dari analisa kebutuhan kemudian dirancang menjadi tampilan-tampilan yang akan mempermudah dalam penggunaan aplikasi.

3. Implementasi, pada tahapan ini hasil dari desain sistem diterjemahkan kedalam tampilan dan kode program.

4. Integrasi dan Pengujian, tahapan selanjutnya adalah integrasi yaitu penggabungan modulmodul menjadi sebuah aplikasi yang utuh, kemudian dari aplikasi tersebut dilakukan pengujian. 
5. Pemeliharan, tahapan ini adalah tahapan terakhir. Setelah aplikasi digunakan maka akan terdapat umpan balik dari pengguna atas pemakaian aplikasi, selanjutnya dilakukan pemeliharaan dan peningkatan aplikasi. Pada metode Software Development

\section{PEMBAHASAN}

\section{Rancangan Model Sistem}

\section{Diagram Konteks}

Diagram konteks merupakan awal pembuatan diagram arus data (DAD), sebelum membuat diagram yang lebih rinci, suatu diagram konteks selalu
Life Cycle (SDLC) saat aplikasi yang telah dibuat masih perlu peningkatan maka tahapan yang harus dilakukan kembali ke tahapan awal (analisa kebutuhan). mengandung satu proses saja, proses ini mewakili proses dari keseluruhan sistem. Diagram konteks menggambarkan hubungan input dan output antara sistem dengan dunia luarnya. Dibawah ini adalah gambar diagram konteks Sistem yang akan diusulkan.

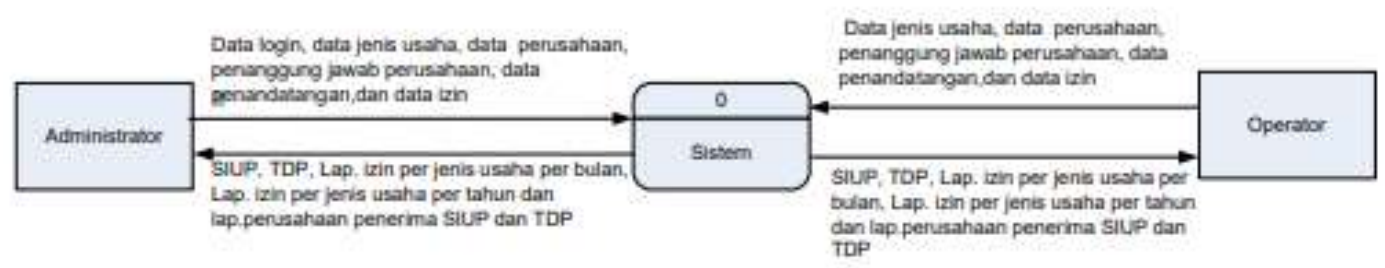

Gambar 1. Konteks Diagram

\section{Tampilan Hasil Aplikasi}

Hasil Aplikasi setelah dijalankan pada Borland Delphi bisa dilihat dibawah ini :

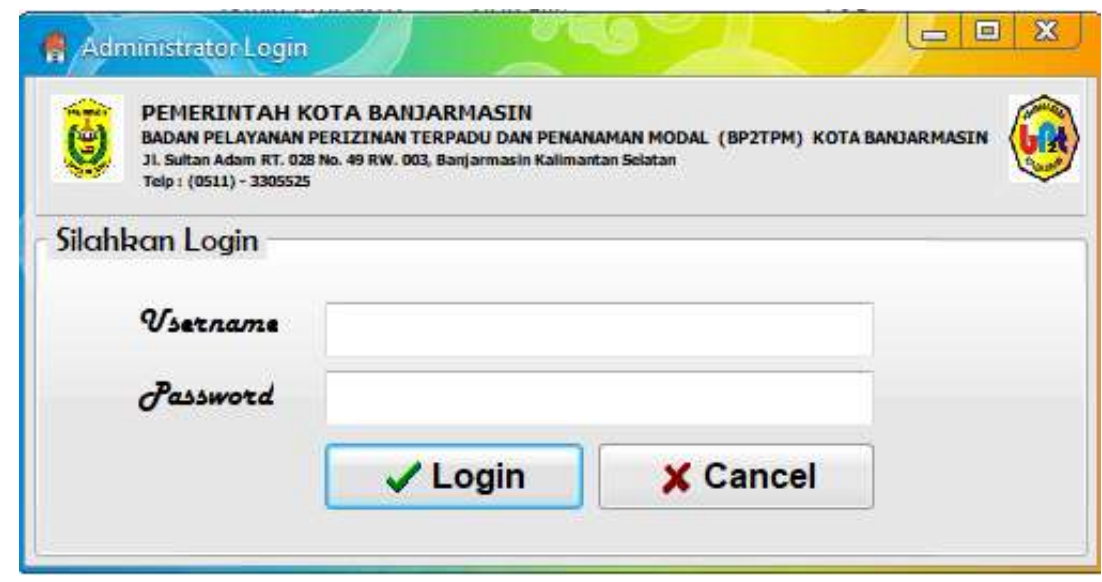

Gambar 2. Login Aplikasi 


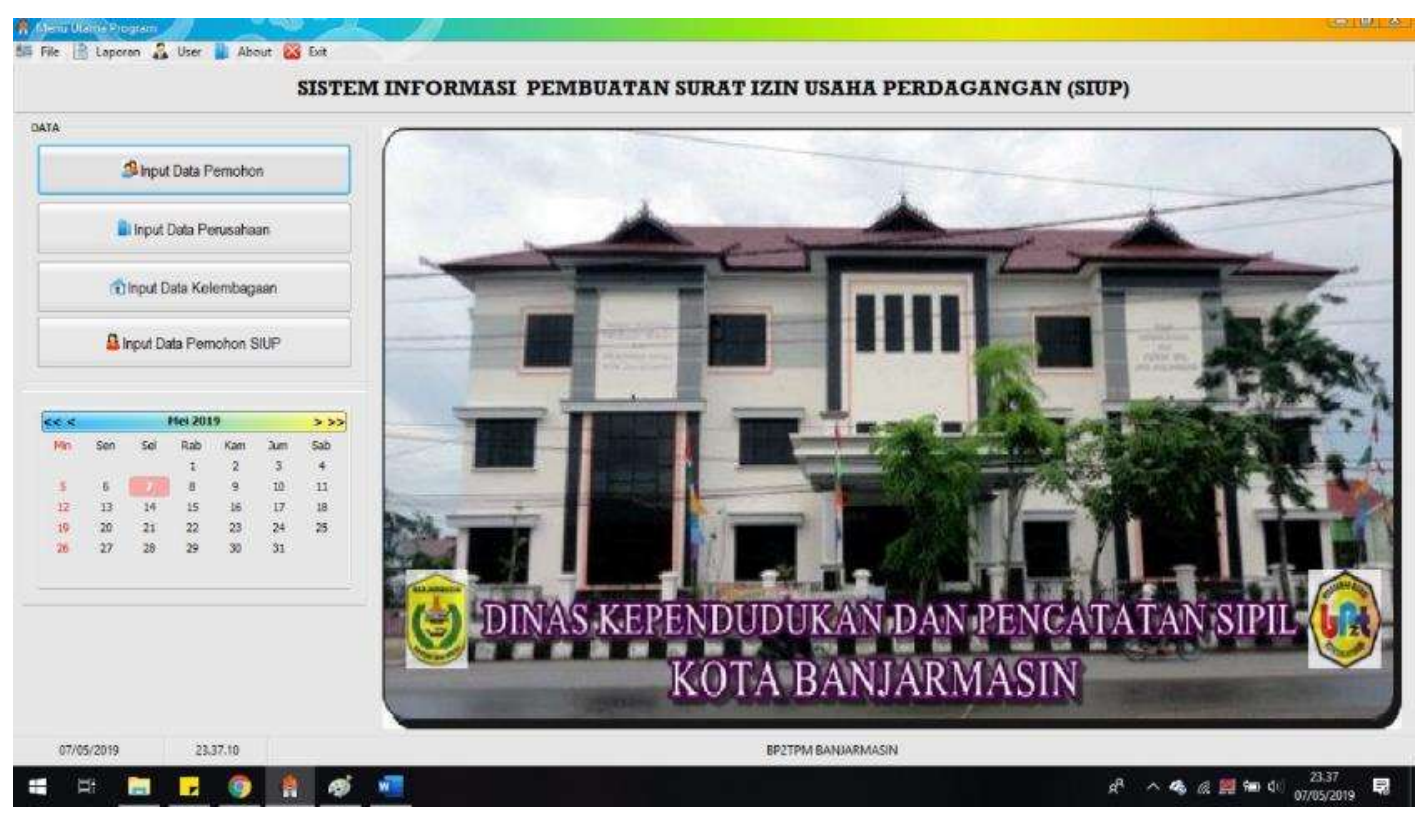

Gambar 3. Menu Utama Aplikasi

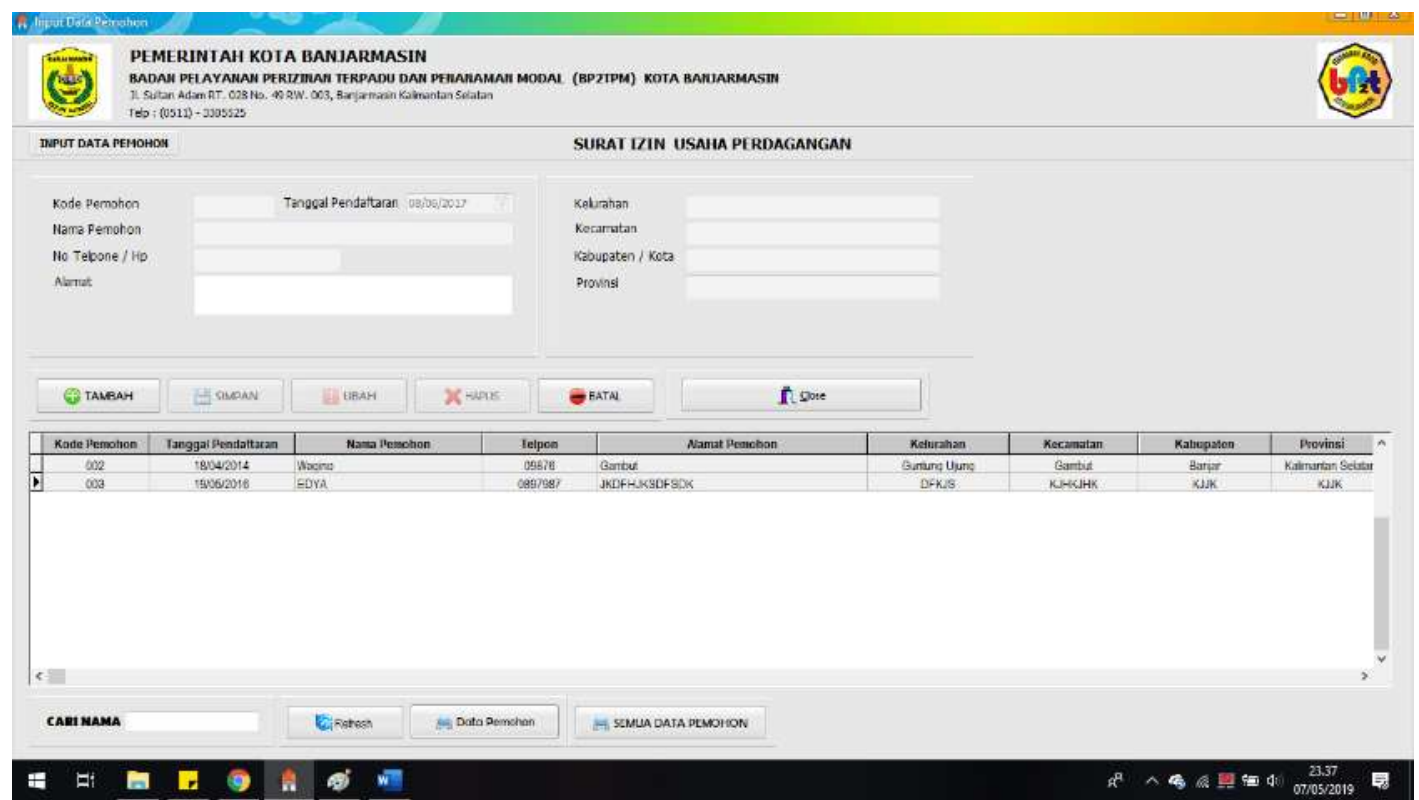

Gambar 4. Input Data Pemohon 


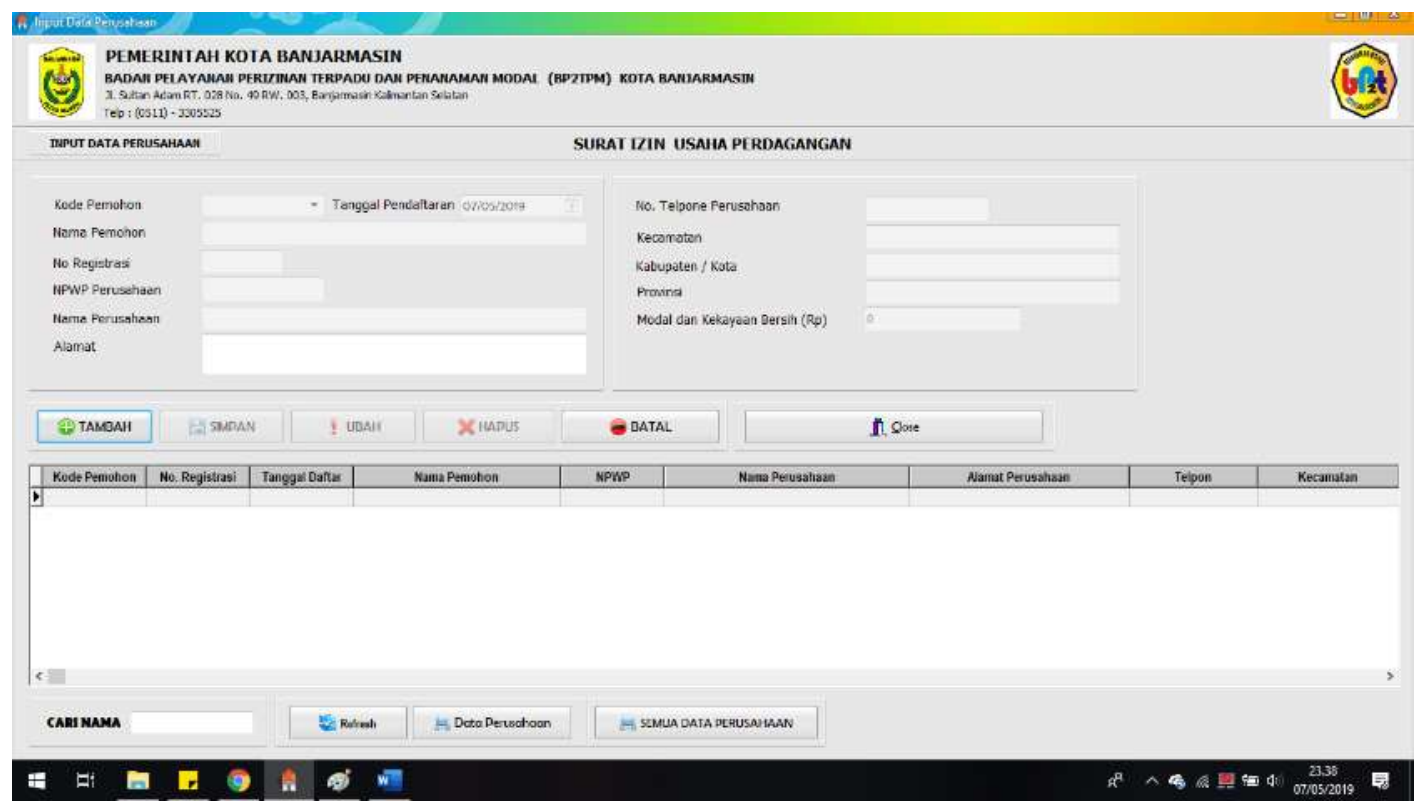

Gambar 5. Input Data Perusahaan

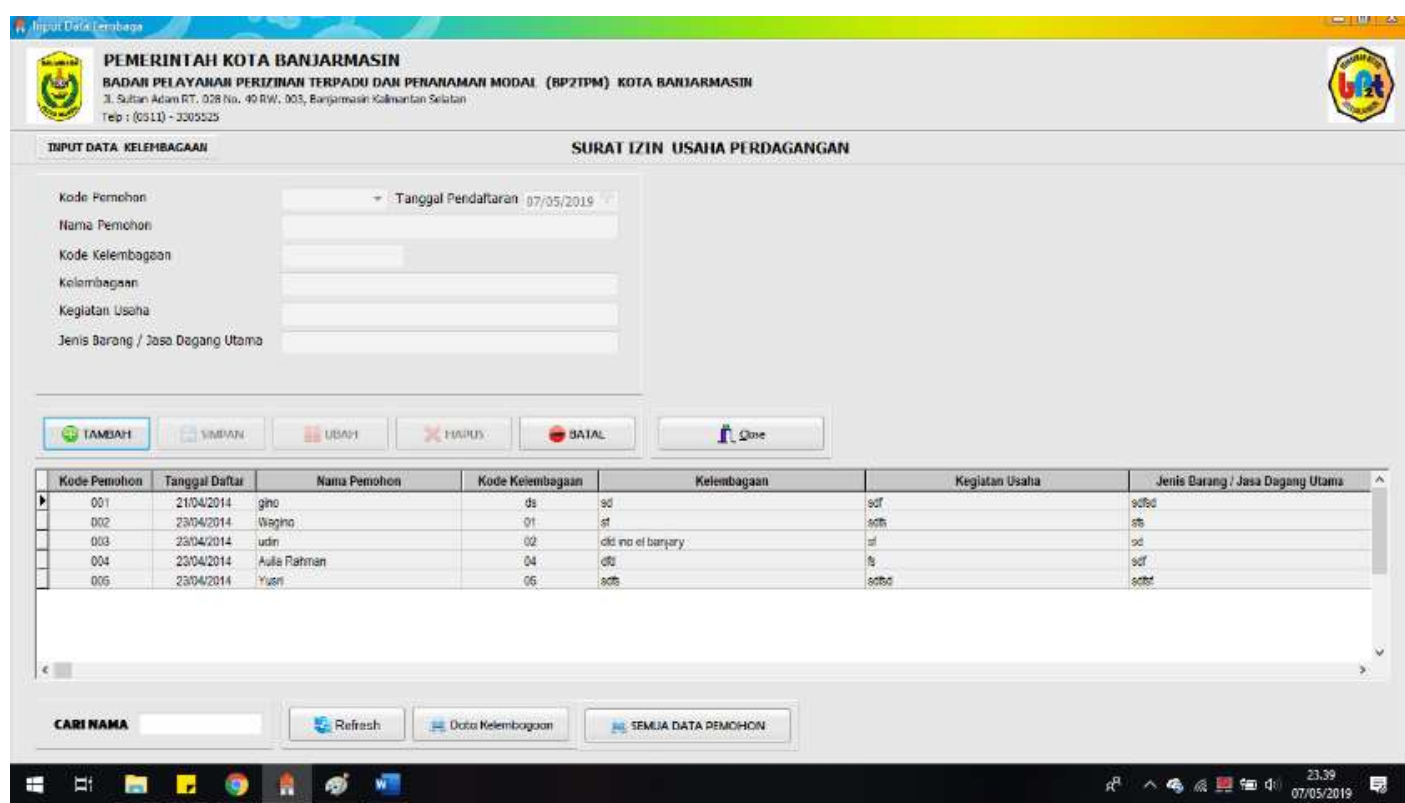

Gambar 6. Input Data Kelembagaan 


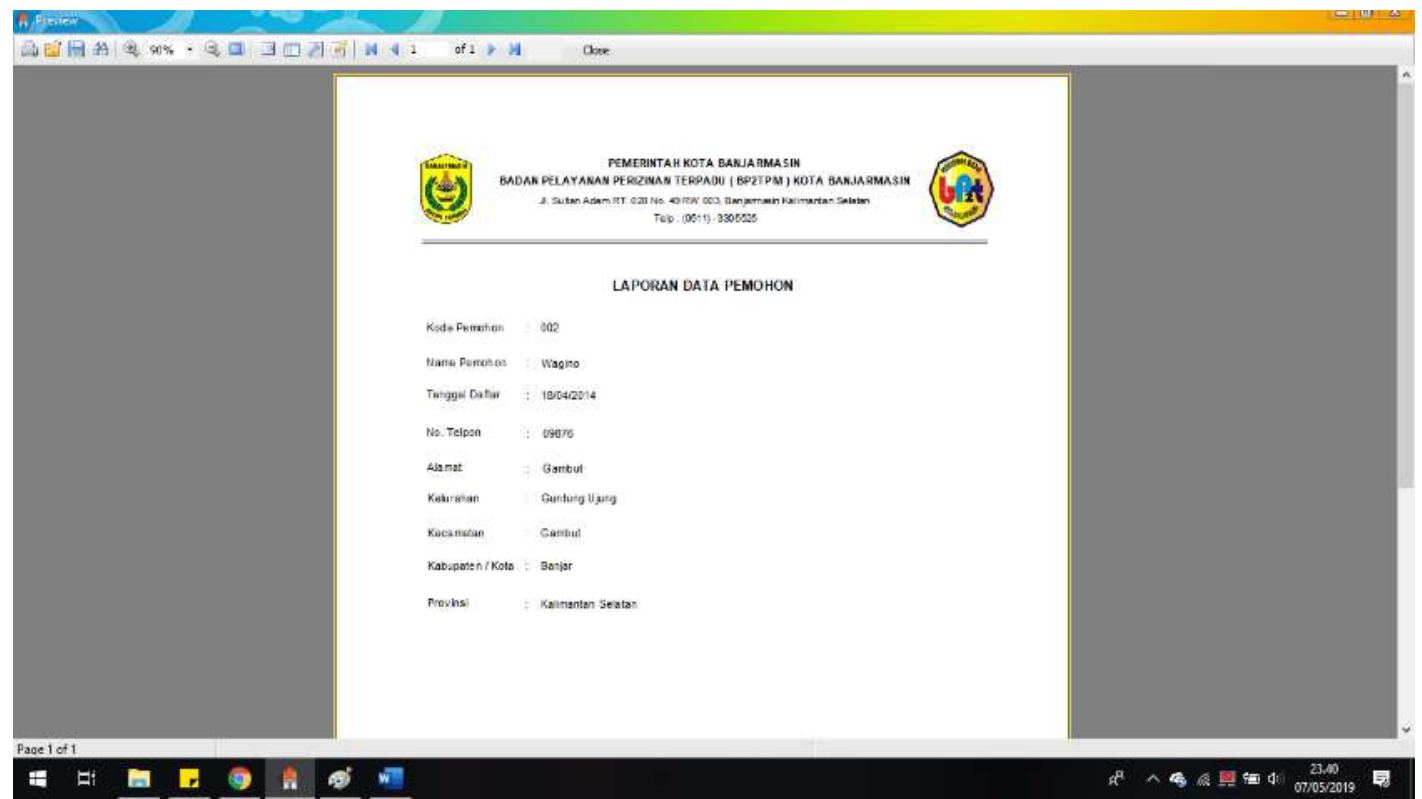

Gambar 7. Laporan Per Data Pemohon

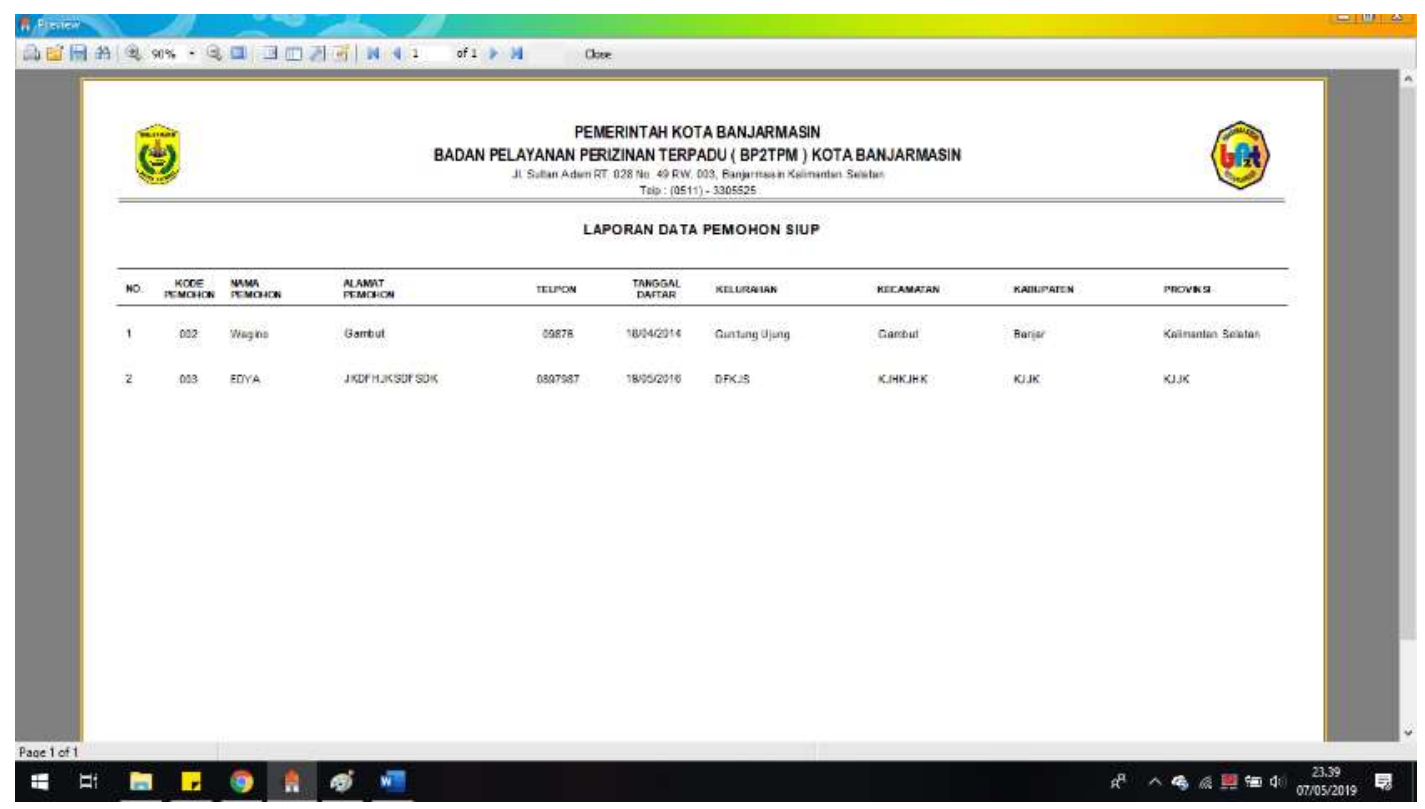

Gambar 8. Laporan Semua Data Pemohon 


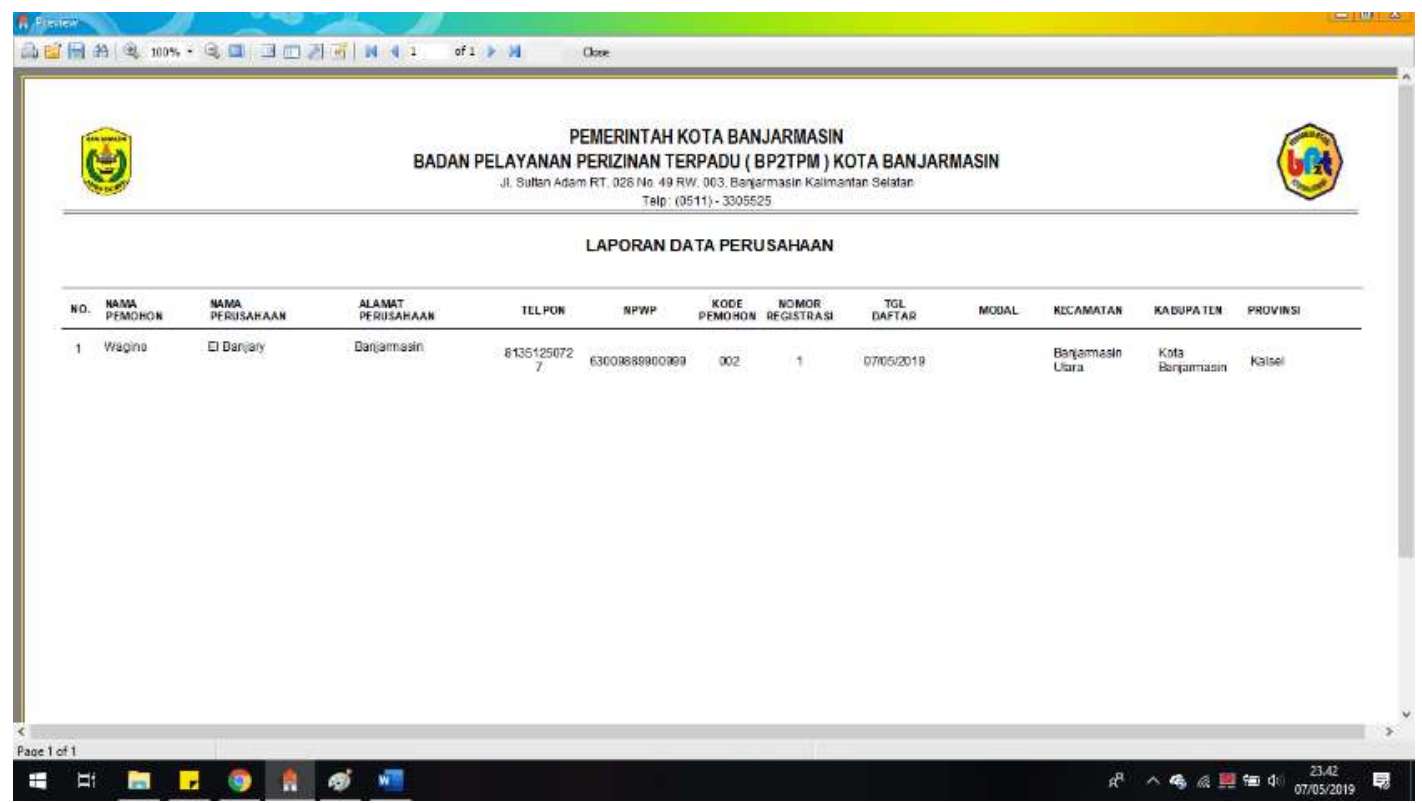

Gambar 9. Laporan Data Perusahaan

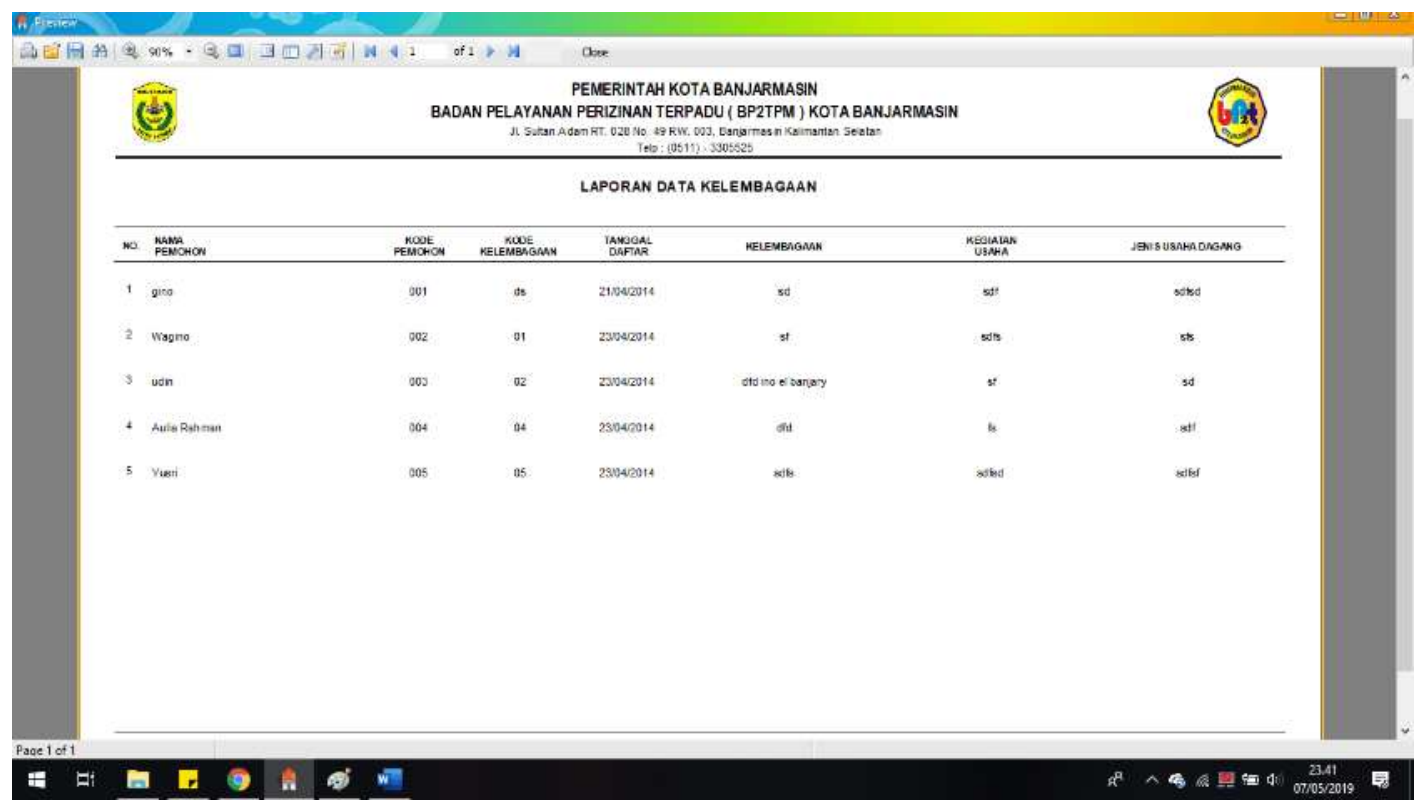

Gambar 10. Laporan Data Kelembagaan 


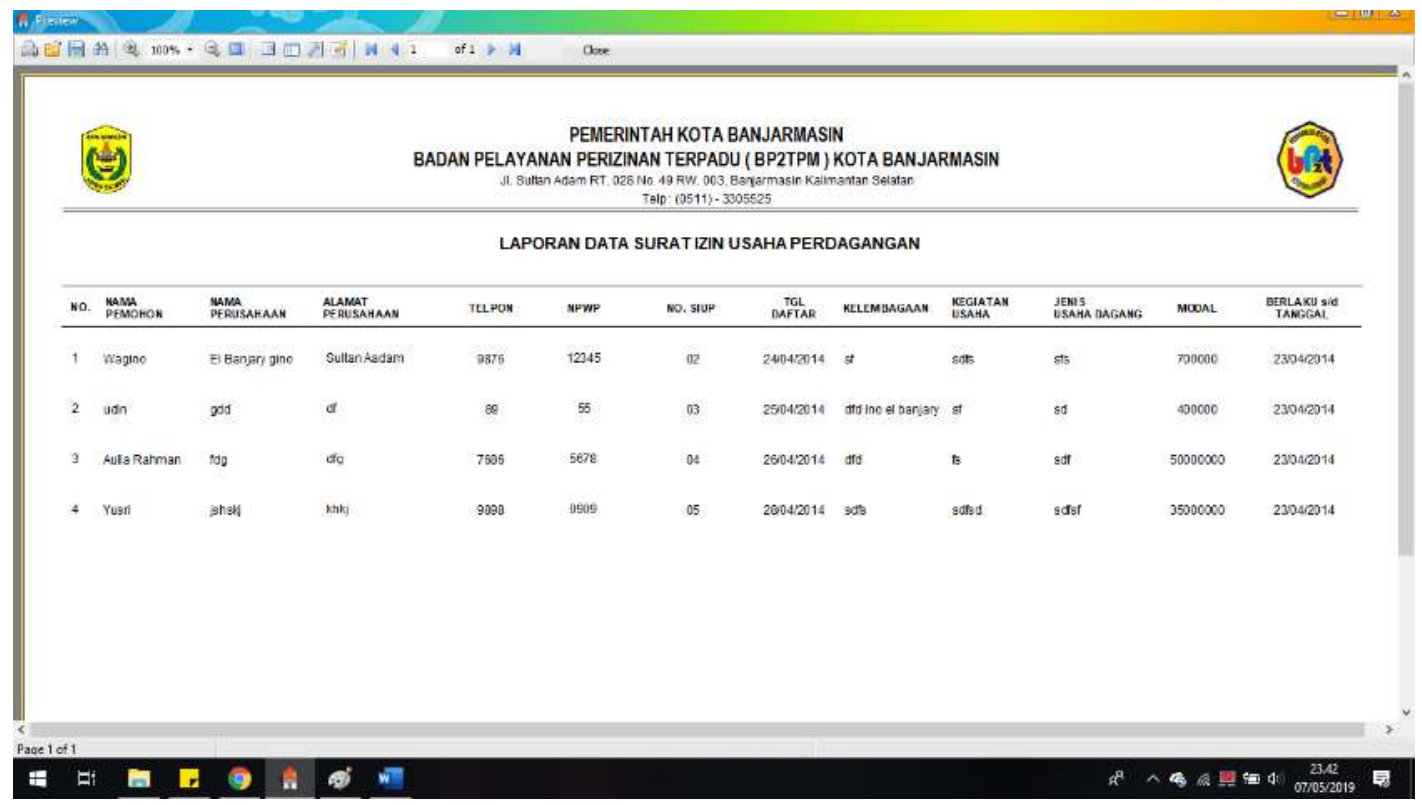

Gambar 11. Laporan Data Surat Izin Usaha Perdagangan

\section{KESIMPULAN}

\section{Kesimpulan}

Dari penelitian yang telah dilakukan dapat diambil kesimpulan diantaranya :

1. Mempermudah dalam proses pendaftaran pembuatan Surat Izin Usaha

2. Pemberkasan lebih rapi dan mudah dicari

3. Pembuatan Laporan Lebih Cepat setelah dibuatkan Aplikasi

\section{Saran}

Penelitian ini masih dapat dikembangkan lebih lanjut sehingga bisa menjadi lebih bagus lagi sesuai dengan perkembangan jaman sekarang, pengembangan yang bisa dilakukan yaitu membuat aplikasi ini menjadi aplikasi berbasis websiter ataupun android.

\section{DAFTAR PUSTAKA}

Kusumawati. 2015. „Perancangan Sistem Informasi Permohonan Surat Izin Usaha Perdagangan pada Dinas Kominfo Pusat Pemerintah Kota Tangerang ${ }^{\text {ee }}$ Skripsi Jurusan Sistem Informasi Sekolah Tinggi Manajemen dan Ilmu Komputer, STIMIK RAHARJA.

Tambotoh J.C \& Latuperissa R 2014, „Kajian Evaluasi Tata Kelola Teknologi Informasi Pada Lembaga Pemerintah Kota Salatiga"e, AITI Jurnal Teknologi Informasi, vol.11, No.01, hh.1532.

Pressman, R. S. (2010). Software Engineering: A Practitioner's Approach. McGraw-Hill Higher Education.

Kurniawaty A. 2012. „Sistem Informasi Perijinan Online Dinas Perindustrian dan Perdagangan Kota Surabaya ${ }^{e e}$. Skirpsi Jurusan Teknik Informatika Politeknik 
Elektronika Negeri Surabaya, Institut Teknologi Sepuluh Nopember.

Supriyanto.2005.Perancangan

Aplikasi.Surabaya : Widyastana

Surjadi. 2009. Pengembangan Kinerja Pelayanan Publik. Bandung: PT. Reflika Aditama
Nazruddin Safaat H. 2012 (Edisi Revisi). Pemograman Aplikasi Mobile Smartphone dan Tablet PC Berbasis Android. Informatika. Bandung.

Y.S Marjo, 2000, Surat-Surat Lengkap, Jakarta : Setia Kawan. 